\title{
Phytochemical Characterization of Phenolic Compounds by LC-MS/MS and Biological Activities of Ajuga reptans L., Ajuga salicifolia (L.) Schreber and Ajuga genevensis L. from Turkey
}

\author{
Türkiye'den Ajuga reptans L., Ajuga salicifolia (L.) Schreber ve Ajuga \\ genevensis L.'nin LC-MS/MS ile Fenolik Bileşiklerinin Fitokimyasal \\ Karakterizasyonu ve Biyolojik Aktiviteleri
}

\author{
(D) Gamze GÖGER ${ }^{1 *}$, (D) Yavuz Bülent KÖSE2 ${ }^{2}$ (D) Fatih DEMIRCi3,4, (D) Fatih GÖGER 3 \\ ${ }^{1}$ Trakya University Faculty of Pharmacy, Department of Pharmacognosy, Edirne, Turkey \\ 2Anadolu University Faculty of Pharmacy, Department of Pharmaceutical Botany, Eskișehir, Turkey \\ ${ }^{3}$ Anadolu University Faculty of Pharmacy, Department of Pharmacognosy, Eskișehir, Turkey \\ ${ }^{4}$ Eastern Mediterranean University Faculty of Pharmacy, Mersin, Turkey
}

\begin{abstract}
Objectives: In this study, it was aimed to characterize the phenolic contents of Ajuga reptans L., Ajuga salicifolia (L.) Schreber and Ajuga genevensis $\mathrm{L}$. and to investigate their in vitro antioxidant and antimicrobial activities.

Materials and Methods: Air dried aerial parts of A. reptans L., A. salicifolia (L.) Schreber, and A. genevensis L. collected from Turkey were extracted with methanol (70\%), and the phenolic composition of the crude extracts was analyzed by liquid chromatography with tandem mass spectrometry (LC-MS/MS) method. To determine the total phenolic content the Folin-Ciocalteu method was used. The radical scavenging activities of the extracts were evaluated by the photometric 1,1-diphenyl-2-picrylhydrazyl radical, and trolox equivalent antioxidant capacity assays (TEAC). Furthermore, Ajuga sp. extracts were tested against Escherichia coli NRRL B3008, Staphylococcus areus ATCC 6538, Salmonella thyphimurium ATCC 13311, Bacillus cereus NRRL B-3711, Candida albicans ATCC 90028, Candida tropicalis ATCC 1369, and Candida parapsilosis ATCC 22019 using the in vitro broth dilution assay.

Results: The LC-MS/MS analyses identified 19 compounds. The amount of total phenolics ranged from 30.0 to $42.2 \mathrm{mg}$ gallic acid equivalent/g in all extracts. According to the results of TEAC assay, the tested extracts were found to have relatively high activity at 1.2-1.5 mM concentrations. Ajuga sp. extracts inhibited all tested microorganisms; however, C. albicans, C. tropicalis, and C. parapsilosis exhibited relatively more susceptibility (minimum inhibitory concentration: $156.25 \mu \mathrm{g} / \mathrm{mL}$ ) compared to the bacteria tested.
\end{abstract}

Conclusion: The antioxidant activities of all extracts were determined for the first time by the TEAK method, and the in vitro antimicrobial activity of $A$. salicifolia was investigated for the first time against selected strains.

Key words: Ajuga reptans, Ajuga salicifolia, Ajuga genevensis, LC-MS/MS, antioxidant activity, antimicrobial activity

öz

Amaç: Bu çalıșmada Türkiye'de yetișen Ajuga reptans L., Ajuga salicifolia (L.) Schreber ve Ajuga genevensis L.'nin fenolik içeriklerinin karakterizasyonu, in vitro antioksidan ve antimikrobiyal aktivitelerinin araştırılması amaçlanmıştır.

Gereç ve Yöntemler: A. reptans L., A. salicifolia (L.) Schreber ve A. genevensis L'nin toprak üstü kısımları metanol (\%70) ile ekstre edilmiş ve liyofilize edilerek ardından sıvı kromatografi tandem kütle/kütle spektrometre (LC-MS/MS) ile karakterizasyonları yapılmıştır. Toplam fenolik madde miktarları Folin-Ciocaltaeu yöntemi ile belirlenmiștir Ekstrelerin radikal süpürücü etkileri 1,1-difenil-2-pikrilhidrazil ve troloks eșdeğeri antioksidan

*Correspondence: gamzegoger@trakya.edu.tr, Phone: +90 28423540 10/3251, ORCID-ID: orcid.org/0000-0003-2978-5385

Received: 17.01.2021, Accepted: 23.02.2021

๑Turk J Pharm Sci, Published by Galenos Publishing House. 
kapasite (TEAK) yöntemleri kullanılarak değerlendirilmiştir. Ayrıca, Ajuga sp. ekstrelerinin antimikrobiyal aktiviteleri, Escherichia coli NRRL B3008, Staphylococcus areus ATCC 6538, Salmonella thyphimurium ATCC 13311, Bacillus cereus NRRL B-3711, Candida albicans ATCC 90028, Candida tropicalis ATCC 1369 ve Candida parapsilosis ATCC 22019'a karşı in vitro mikrodilüsyon yöntemiyle çalışılmıștır.

Bulgular: LC-MS/MS analizleriyle 19 fenolik bileşik tanımlanmıştır. Tüm ekstrelerde toplam fenol miktarı 30,0-42,2 mg gallik asit eșdeğeri/g arasında bulunmuştur. TEAK antioksidan aktivite sonucunda ekstreler (1,2-1,5 mM) konsantrasyonlarda nispeten yüksek aktivite göstermiștir. Ajuga sp. ekstreleri, test edilen tüm mikroorganizmalara karşı antimikrobiyal aktivite göstermiştir. Ancak ekstreler, test edilen bakterilere kıyasla $C$. albicans, C. tropicalis ve C. parapsilosis suşlarına karşı nispeten daha fazla etkili (minimal inhibisyon konsantrasyonu: 156,25 $\mu \mathrm{g} / \mathrm{mL}$ ) bulunmuştur.

Sonuç: TEAK yöntemi ile tüm ekstrelerin ilk defa antioksidan aktiviteleri belirlenmiștir ve $A$. salicifolia'nın in vitro antimikrobiyal aktivitesi seçilen suşlara karşı ilk kez incelenmiştir.

Anahtar kelimeler: Ajuga reptans, Ajuga salicifolia, Ajuga genevensis, LC-MS/MS, antioksidan aktivite, antimikrobiyal aktivite

\section{INTRODUCTION}

The Lamiaceae family includes more than 245 genera and 7886 species distributed worldwide. ${ }^{1}$ Ajuga $\mathrm{L}$. is a genus of annual and perennial herbaceous flowering plants in the Lamiaceae family, with most species native to Asia, Africa, and Europe. Ajuga is represented by 14 species and 27 taxa in Turkey. ${ }^{2}$

Ajuga has a long history of use for wound healing preparation, and although little used today, it is well known in Anatolia as "Mayasil otu". Some Ajuga species are widely consumed as diuretic, diaphoretic, astringent, antipyretic, and tonic in Turkish traditional medicine. ${ }^{3}$

Ajuga sp. plants are reported for their in vitro antimalarial, ${ }^{4}$ antimicrobial, ${ }^{5,6}$ antioxidant, ${ }^{5}$ anti-inflammatory, ${ }^{7}$ lipoxygenase, acetylcholinesterase, and butyrylcholinesterase inhibition, ${ }^{8}$ antipyretic, ${ }^{9}$ and antiproliferative ${ }^{10}$ activities.
Phytochemical constituents diterpenoids, such as phenylethanoid glycosides, sterols, phytoecdysteroids, flavonoids, and iridoids were reported as the main active compounds in Ajuga L. species."

Ajuga salicifolia sterol glycosides were isolated and tested for antimicrobial and cytotoxic activity.12 Iridoid, ionone, and phenylethanoid glycosides from the same group were also reported for this species. ${ }^{13}$

Phytochemical profile of Romanian Ajuga genevensis L. and $A$. reptans reptans were recently reported. ${ }^{6} A$ summary of phytochemical investigations on $A$. salicifolia, A. reptans, and $A$. genevensis species are listed in Table 1.6-36 In vitro antioxidant and antimicrobial activity of different extracts of Romanian $A$. genevensis $\mathrm{L}$. and $A$. reptans were recently reported. ${ }^{6}$ Previous antimicrobial activity results of $A$. reptans, $A$. genevensis and $A$. salicifolia are listed in Table 2.37-40

Table 1. Literature data on phytochemical profile for Ajuga species

\begin{tabular}{|c|c|c|}
\hline Species & Compounds & References \\
\hline Ajuga reptans & Iridoid glycoside (ajureptaside) & 19 \\
\hline Ajuga reptans & Iridoid glucosides (ajureptaside A-D) & 24 \\
\hline Ajuga salicifolia & Iridoid, ionone and phenylethanoid glycosides (8-O-acetylharpagide corchoionoside $\mathrm{C}$, leonosides A) & 13 \\
\hline Ajuga genevensis & Neo-clerodane diterpenoids (ajugavensins A-C) & 18 \\
\hline Ajuga salicifolia & Sterol glycosides (ajugasalicioside A-E) & 12 \\
\hline Ajuga reptans & Phytoecdysteroids (28-Epi-sengosterone) & 36 \\
\hline Ajuga salicifolia & Stigmastane sterols (ajugasalicigenin) & 22 \\
\hline $\begin{array}{l}\text { Ajuga genevensis } \\
\text { Ajuga reptans }\end{array}$ & Hydroxycinnamic acids (caffeic acid, chlorogenic acid), flavonoids (apigenin and luteolin-7-0-glucoside) & 17 \\
\hline Ajuga genevensis & $\begin{array}{l}\text { Hydroxycinnamic acids (caffeic acid, } p \text {-coumaric acid, ferulic acid), flavonoids (hyperoside, isoquercitrin, } \\
\text { rutin, quercitrin, luteolin, apigenin) }\end{array}$ & 6 \\
\hline Ajuga reptans & $\begin{array}{l}\text { Hydroxycinnamic acids ( } p \text {-coumaric acid, ferulic acid), flavonoids (isoquercitrin, rutin, quercitrin, luteolin, } \\
\text { apigenin) }\end{array}$ & 6 \\
\hline
\end{tabular}


Table 2. Literature survey of antimicrobial activity for Ajuga salicifolia, Ajuga genevensis, and Ajuga reptans

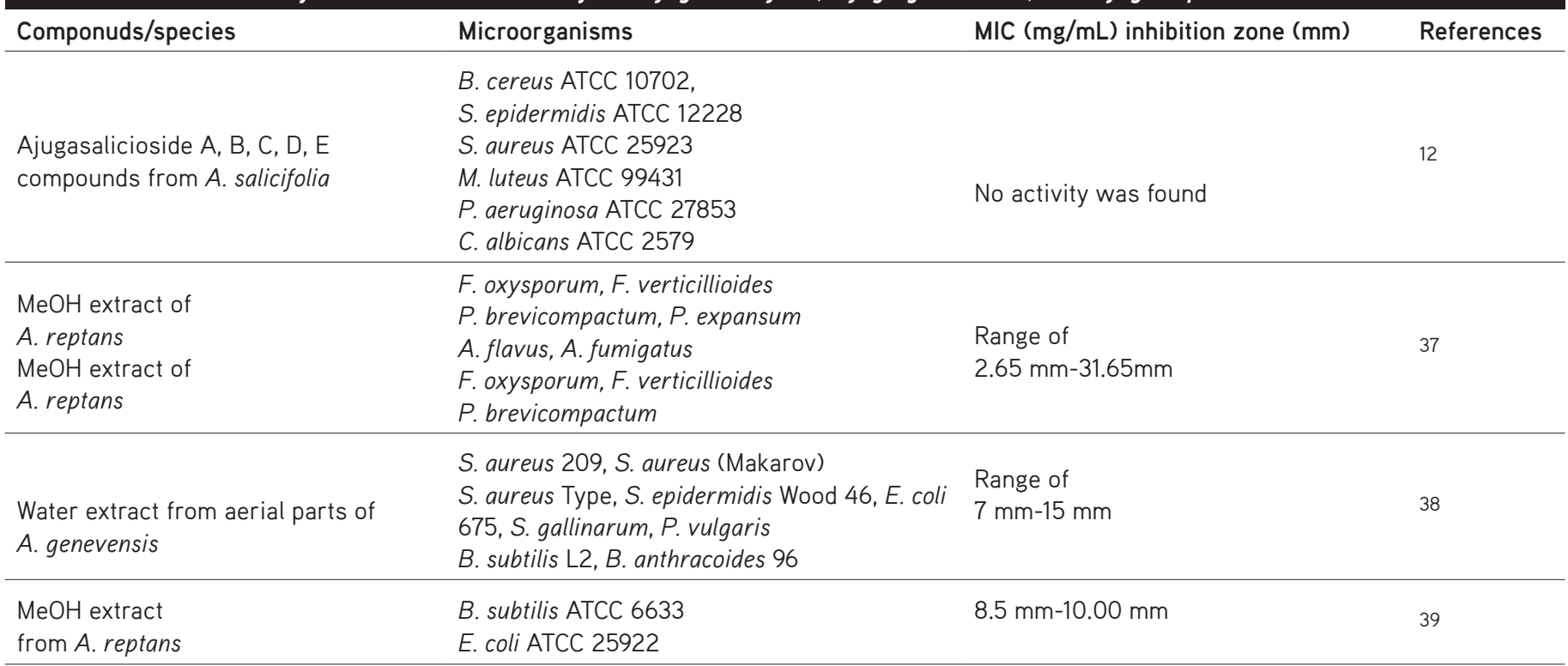

E. coli ATCC 25922, P. aeruginosa ATCC 27853, S. typhimurium ATCC 14028, S. marcescens ATCC 8100

Water, $\mathrm{MeOH}$ and $\mathrm{EtOH}$ extracts from P. vulgaris ATCC 13315, E. cloacae ATCC aerial parts of $A$. reptans 23355, K. pneumoniae ATTC 13883, S. pyogenes ATTC 19615

$7.0 \mathrm{~mm}-11.7 \mathrm{~mm}$

S. aureus ATTC 25923, S. epidermidis ATCC 12228

\begin{tabular}{|c|c|c|c|}
\hline $\begin{array}{l}\mathrm{MeOH} \text { and } \mathrm{EtOH} \text { extracts from flowers } \\
\text { of } A \text {. genevensis }\end{array}$ & $\begin{array}{l}\text { S. aureus ATCC } 49444, \text { P. aeruginosa ATCC } \\
27853, \text { L.monocytogenes ATCC 19114, E. coli } \\
\text { ATCC } 25922 \\
\text { S. typhimurium ATCC } 14028\end{array}$ & $\begin{array}{l}\text { MIC value of } \\
1.56-6.25\end{array}$ & 29 \\
\hline $\begin{array}{l}\mathrm{MeOH} \text { and } \mathrm{EtOH} \text { extracts from flowers } \\
\text { of } A \text {. reptans }\end{array}$ & $\begin{array}{l}\text { S. aureus ATCC 49444, P. aeruginosa ATCC } \\
27853, \text { L. monocytogenes ATCC 19114, E. coli } \\
\text { ATCC } 25922 \\
\text { S. typhimurium ATCC } 14028\end{array}$ & $\begin{array}{l}\text { MIC value of } \\
1.56-6.25\end{array}$ & 28 \\
\hline $\begin{array}{l}\text { EtOH, PE and Chl. extracts } \\
\text { from aerial parts of } \\
\text { A. genevensis }\end{array}$ & $\begin{array}{l}\text { A. flavus ATCC } 9643 \text {, A. niger ATCC } 6275, \text { C. } \\
\text { albicans ATCC 10231, C. parapsilosis ATCC } \\
22019 \text {, P. funiculosum ATCC } 56755 \text {, } \\
\text { A. flavus ATCC } 9643\end{array}$ & $\begin{array}{l}\text { MIC value of } \\
0.05-0.1\end{array}$ & 6 \\
\hline $\begin{array}{l}\text { EtOH, PE and Chl. extracts } \\
\text { from aerial parts of } \\
\text { A. reptans }\end{array}$ & $\begin{array}{l}\text { A. niger ATCC } 6275 \\
\text { C. albicans ATCC } 10231 \\
\text { C. parapsilosis ATCC } 22019 \\
\text { P. funiculosum ATCC } 56755\end{array}$ & $\begin{array}{l}\text { MIC value of } \\
0.05-0.025\end{array}$ & 6 \\
\hline
\end{tabular}

A. genevensis was used in traditional Austrian medicine and consumed as medicinal tea in treating respiratory tract disorders, ${ }^{14}$ and in vitro anticancer activity studies were reported from Europe, Asia, and America. ${ }^{15}$

A. reptans grows natively in Europe and have bluish-purple flowers colored with anthocyanin pigments." It was used in Mediterranean traditional medicine for cardiovascular complications and skin disorders ${ }^{16}$ and in traditional Austrian medicine as a medicinal tea for the treatment of respiratory tract disorders. ${ }^{14}$ A previous study showed that $A$. reptans $L$. is used due to the anti-inflammatory effects of its polyphenols, its wound healing properties, and antidiarrhea, antiulcerogenic, and hepatoprotective effects due to the presence of iridoids. ${ }^{17}$ In the present study, $70 \%$ methanol extract of aerial parts of $A$. reptans L., A. salicifolia (L.) Schreber, and $A$. genevensis L. from Turkey were evaluated for their phytochemical profiles, total phenol, and total flavonoid contents, as well as their in vitro antioxidant and antimicrobial activities. LC-MS/MS techniques 
were used for phytochemical analyses. In vitro 1,1-diphenyl-2picrylhydrazyl (DPPH) radical, and trolox equivalent antioxidant capacity (TEAC) assays were performed. Additionally, antimicrobial properties of Ajuga extracts were assessed against microbial strains of Escherichia coli NRRL B3008, Staphylococcus areus ATCC 6538, Salmonella thyphimurium ATCC 13311, Bacillus cereus NRRL B-3711, Candida albicans ATCC 90028, Candida tropicalis ATCC 1369, and Candida parapsilosis ATCC 22019.

To the best of our knowledge, this is the first study to perform the TEAC antioxidant activity for all extracts and the in vitro antimicrobial activity of $A$. salicifolia.

\section{MATERIALS AND METHODS}

\section{Chemicals}

Antimicrobial standards, Mueller Hinton Broth, and RPMI1640 medium were purchased from Sigma-Aldrich Chemical Co (Sigma-Aldrich Corp., St. Louis, MO). All chemicals and solvents used were of analytical grade.

\section{Plant materials}

A. reptans L.: [A1(E) Kırklareli: İğneada, Fidanlık kavşağı, 350 m, N 41 52' 25.3" E 27 56' 11'", 21 Iv 2009], A. salicifolia (L.) Schreber: (B3, Eskișehir: Çağlan köyü, 1000 m, K 390 39' 971" D 300 31' 185", 31 vi 2010), and A. genevensis L. [A1(E) Kırklareli: Dereköy yolu, 449 m, K 410 50' 6.13 D 270 18' 3.18", 22 Iv 2009] were collected and identified by Dr. Y.B Köse, and herbarium materials were deposited in the Herbarium of Anadolu University, Faculty of Pharmacy under herbarium code YBK1560, YBK1575, and YBK 1561, respectively.

\section{Preparation of extracts}

The aerial parts of the plants were dried in the shade at room temperature and ground to powder in a mechanical grinder. Each species $(1 \mathrm{~g})$ was extracted with methanol $(70 \%, 100 \mathrm{~mL})$ for $24 \mathrm{~h}$, three times a day. After filtration, the solvents were evaporated under vacuo.

Phytochemical analysis by liquid chromatography with tandem mass spectrometry (LC-MS/MS)

The phytochemical analyses were performed using LC-MS/MS techniques. $^{5}$

\section{Determination of phenolic compounds}

The total phenols contained in the extracts were calculated using the Folin-Ciocalteu method equivalent to gallic acid $(\mathrm{GA}){ }^{30} \mathrm{~A}$ sample solution $(100 \mu \mathrm{L})$ and Folin-Ciocalteu reagent $(500 \mu \mathrm{L}$ ) were added to a $10 \mathrm{~mL}$ scale vessel containing $6 \mathrm{~mL}$ of distilled water. After $1 \mathrm{~min}, 1.5 \mathrm{~mL}$ of $20 \%$ aqueous $\mathrm{Na}_{2} \mathrm{CO}_{3}$ was added and completed with water to reach $10 \mathrm{~mL}$. The reagentfree of extracts was used as the control. After incubation at $25^{\circ} \mathrm{C}$ for $2 \mathrm{~h}$, the absorbance was read at $760 \mathrm{~nm}$ and compared with the GA calibration curve. The total amount of phenolic was calculated as equivalent to GA. Three parallel experiments were performed, and the results were reported as mean values.

\section{Biological activity}

\section{$D P P H$ radical scavenging assay}

The DPPH radical scavenging activity was performed according to Kumarasamy et al. ${ }^{31}$ For this purpose, $100 \mu \mathrm{L}$ of methanol and samples were transferred to the first column of 96-well microtiter plates. A 10 -well dilution was made in an equal amount of $\mathrm{MeOH}$ via a multi-channel pipette and stirred in the vortex for $5 \mathrm{~min}$. The DPPH stock solution was prepared by dissolving $2 \mathrm{mg}$ of $\mathrm{DPPH}{ }^{\bullet}$ in $25 \mathrm{~mL}$ of $\mathrm{MeOH}$, and solution was added to each well and left in a dark place for $30 \mathrm{~min}$. Butylated hydroxy toluene (BHT) and GA at the same concentration were used as positive controls, and ultraviolet (UV) absorbance was measured at room temperature using a Biotek microplate spectrophotometer at $517 \mathrm{~nm}$.

The following equations using $50 \%$ inhibition concentration $\left(\mathrm{IC}_{50}\right.$ ) (equation 1 ) and percentage $(\%)$ inhibition values (equation 2) were calculated as follows:

$I C_{50}=\left[\left(A_{0}-A_{1}\right) / A_{0}\right] \times 100$ equation (1)

Percentage Inhibition $=\left[\frac{(\mathrm{Abs} \text { control }- \text { Abs sample })}{A b s \text { control }}\right] x 100$ equation (2)

\section{TEAC assay}

Experiments were performed as declared by Papandreou et al. $^{32}$ sweeping ABTS ${ }^{\bullet+}$ (2,2'-azino-bis-3-ethylbenzothiazoline6 -sulfonic acid) radical and vitamin $E$. It is based on the comparison of water-soluble analog with trolox. The mixture of $7 \mathrm{mM} \mathrm{ABTS}^{\bullet+}$ and $2.5 \mathrm{mM}$ sodium persulfate was kept in the dark for $12-16 \mathrm{~h}$, resulting in the formation of blue-colored radicals. A sample $(10 \mu \mathrm{L})$ and $A B T S^{\bullet+}$ solution $(990 \mu \mathrm{L})$ were mixed, and absorbance was measured at $734 \mathrm{~nm}$ per minute intervals for $30 \mathrm{~min}$. To find out the TEAC activity results, the ABTS $^{\bullet+}$ radical was plotted using Trolox's 2.5-2-1.5-1-0.5-0.1 $(\mathrm{mM})$ concentrations, according to the \% inhibition values. For quantification, a Trolox calibration curve was used where all experiments were repeated in triplicates.

\section{Antimicrobial activity}

Antimicrobial activity testing was performed according to the guidelines of broth microdilution methods. ${ }^{33-35}$ Standard strains, E. coli NRRL B3008, S. areus ATCC 6538, S. thyphimurium ATCC 13311, B. cereus NRRL B-3711, C. tropicalis ATCC 1369, C. parapsilosis ATCC 22019, and C. albicans ATCC 90028, as well as antimicrobial standards, such as ampicillin, tetracycline, ketoconazole, and oxiconazole, were used in this study. Methanol extracts were prepared at 1250-2.44 $\mu \mathrm{g} / \mathrm{mL}$ concentrations and dissolved in dimethylsulfoxide and initial test solutions. Serial dilutions were prepared at $64-0.125 \mu \mathrm{g} / \mathrm{mL}$ for ampicillin, tetracycline, and ketoconazole. All experiments were evaluated in triplicates, and mean values were reported.

\section{Statistical analysis}

Data obtained from antioxidant and total phenolic content experiments were expressed as mean standard error. $I_{50}$ values were estimated using a non-linear regression algorithm. 


\section{RESULTS AND DISCUSSION}

\section{LC-MS/MS analysis of the extracts}

Screening of the extracts by LC-MS/MS enabled the identification of phenolic acids, such as coumaroyl glucoside, flavonoids, and phenylethanoid glycosides. Figures 1-3 show the $280 \mathrm{~nm}$ UV chromatograms of $A$. reptans, A. genevensis and A. salicifolia, respectively. The compounds detected from Ajuga sp. methanol extracts are listed in Table 3.

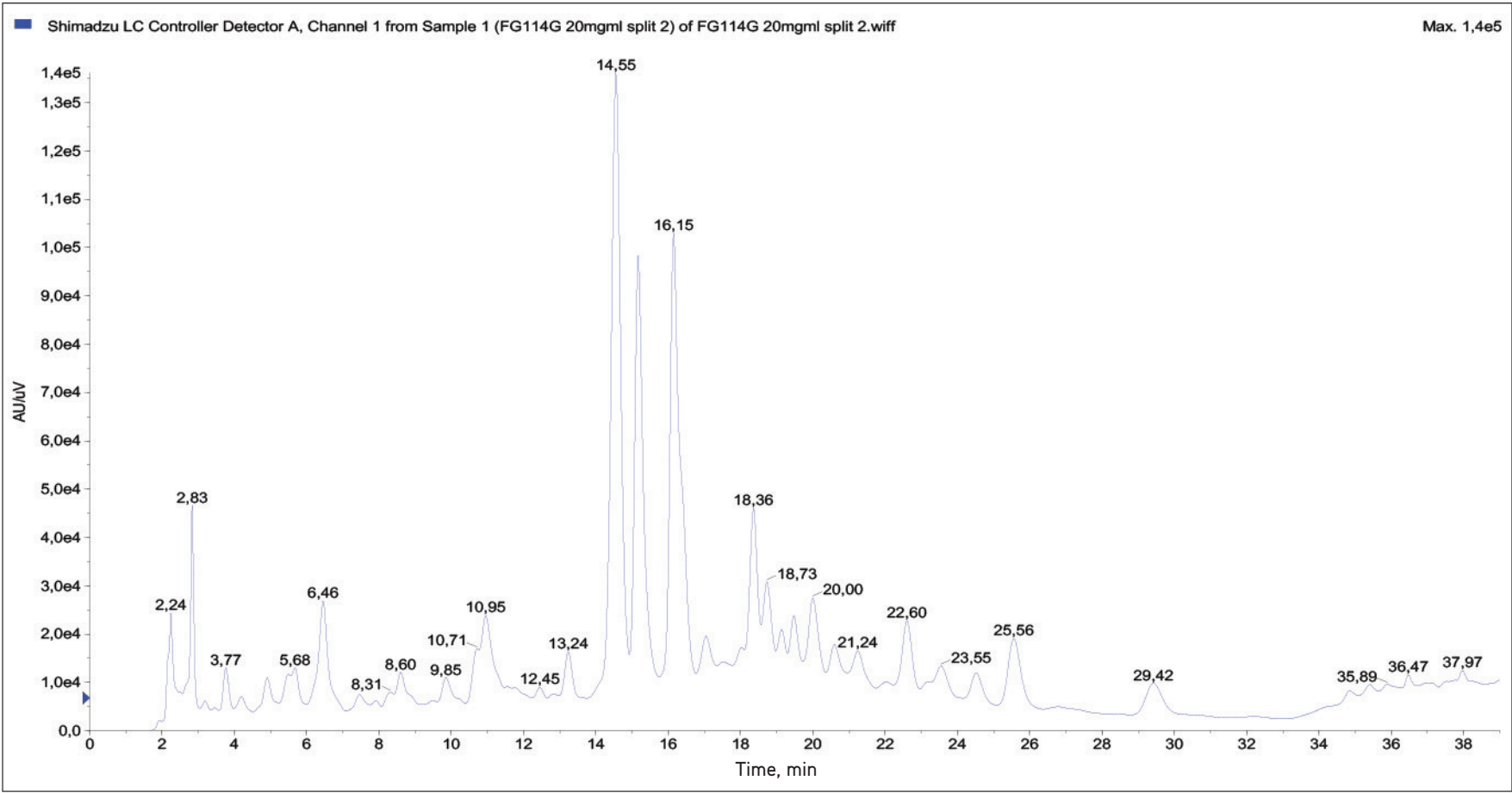

Figure 1. HPLC-UV chromatogram ( $280 \mathrm{~nm}$ ) of $A$. reptans HPLC: High performance liquid chromatography, UV: Ultraviolet
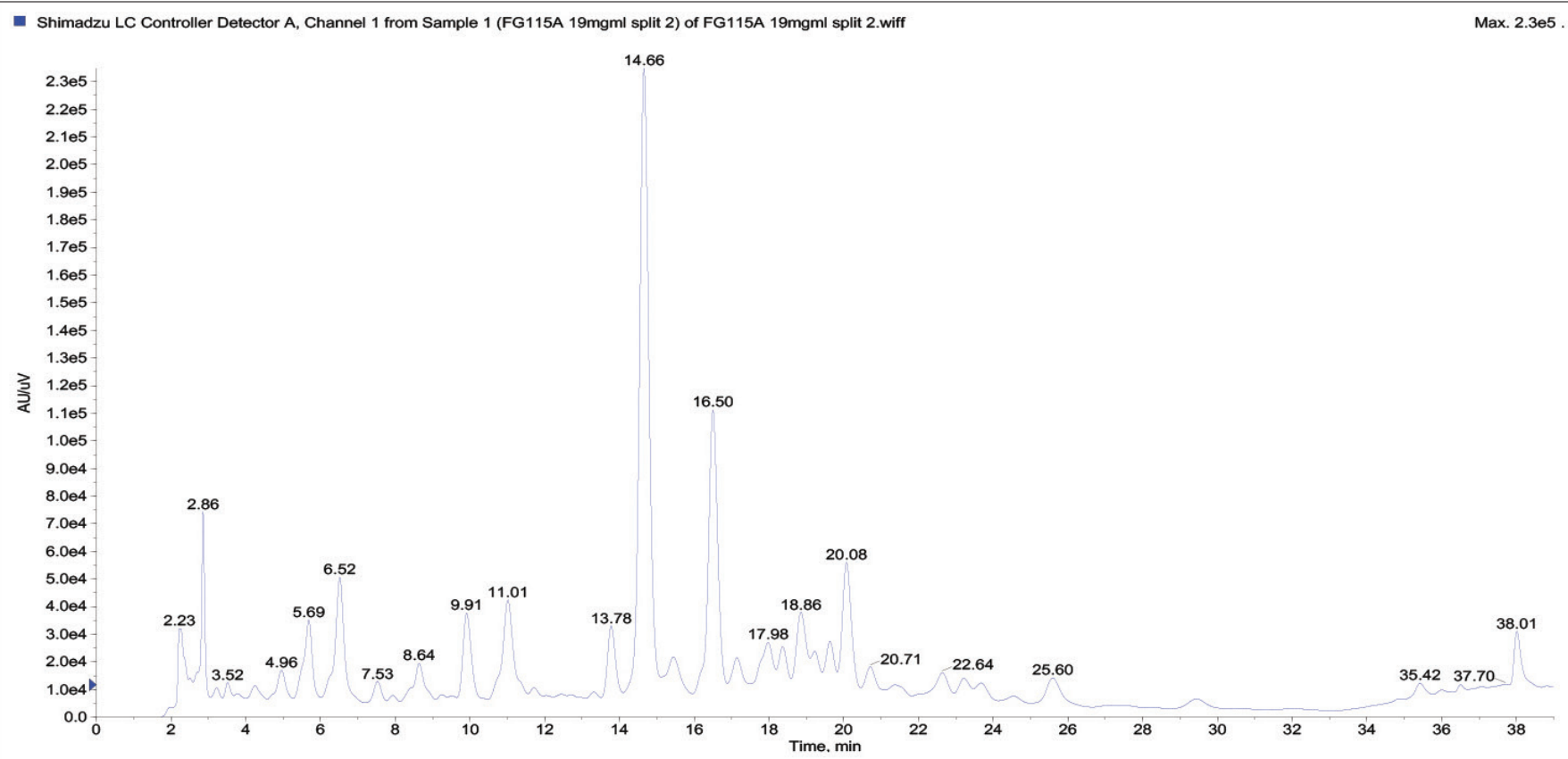

Figure 2. HPLC-UV chromatogram ( $280 \mathrm{~nm}$ ) of $A$. genevensis HPLC: High performance liquid chromatography, UV: Ultraviolet 


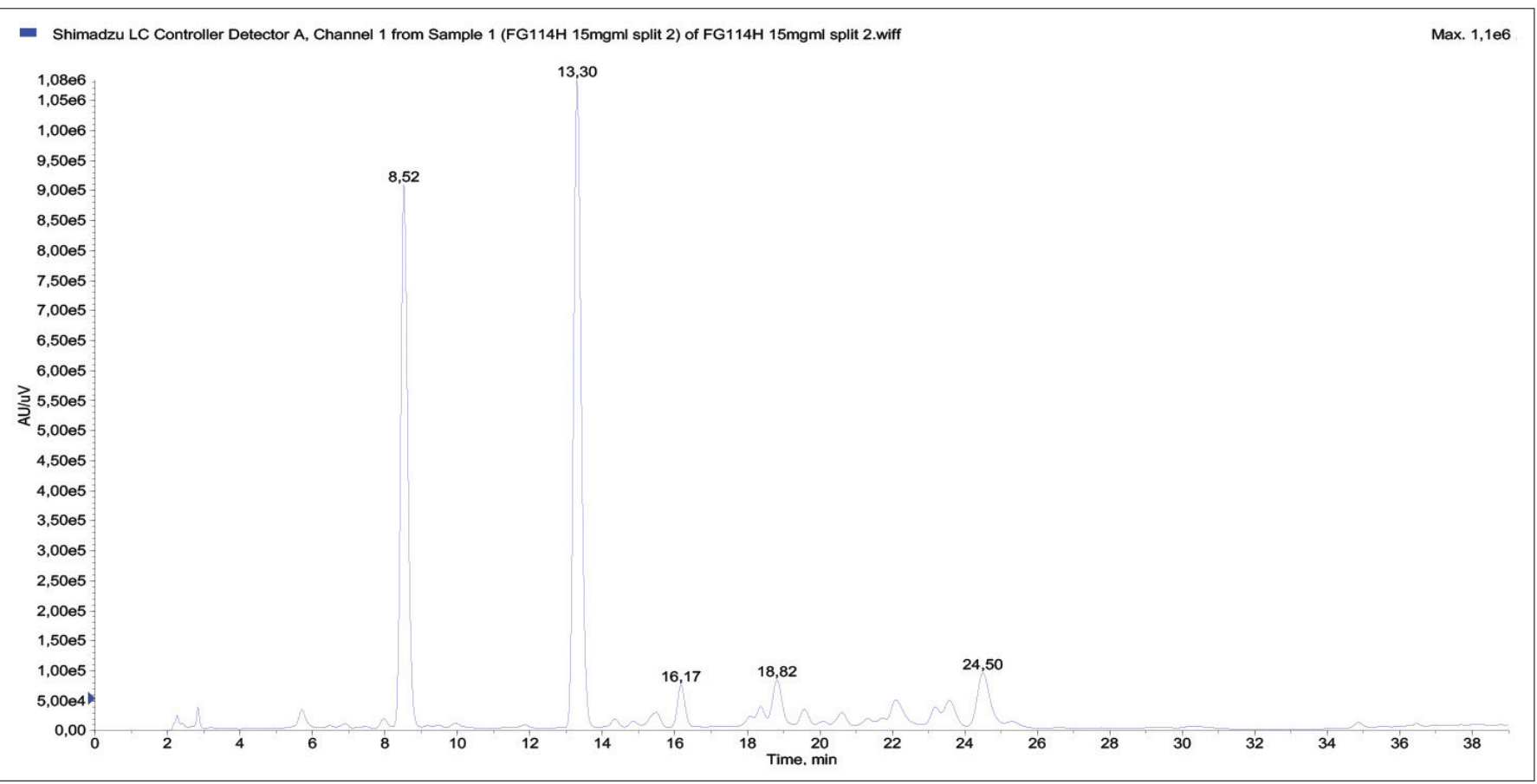

Figure 3. HPLC-UV chromatogram ( $280 \mathrm{~nm}$ ) of $A$. salicifolia HPLC: High performance liquid chromatography, UV: Ultraviolet

\begin{tabular}{|c|c|c|c|c|c|c|}
\hline No & Compound & Rt & {$[\mathrm{M}-\mathrm{H}]^{-}$} & Fragments & Plant & Reference \\
\hline 1 & Caffeoyl glucose & 6.4 & 341 & $179,161,133$ & $\mathrm{R}$ & 41 \\
\hline 2 & Coumaroyl glucoside & 8.5 & 325 & 163,119 & $\mathrm{~S}$ (major), G & 41,42 \\
\hline 3 & Caffec acid & 11.2 & 179 & 135 & G & - \\
\hline 6 & Apigenin-C-hexoside-C-pentoside & 14.7 & 563 & $443,383,353$ & G & 44 \\
\hline 7 & Echinocoside & 15.4 & 785 & $623,461,161$ & $\mathrm{R}$ (major) & 44 \\
\hline 8 & Forsythoside B & 15.6 & 755 & $593,461,161$ & $\mathrm{~S}$ & 45 \\
\hline 12 & Quercetin glucuronide & 19.0 & 477 & $301,227,133$ & G & 47 \\
\hline 13 & Verbascoside & 19.2 & 623 & $461,315,161$ & $\mathrm{R}$ & - \\
\hline 14 & Leucoseptoside A & 19.6 & 637 & 461,175 & $R, S$ & 45 \\
\hline 15 & Luteolin glucuronide & 20,1 & 461 & 285 & R, G (major) & 43 \\
\hline 16 & Luteolin glucoside & 21.6 & 447 & 285 & $\mathrm{~S}$ & 46 \\
\hline 17 & Luteolin & 35.4 & 285 & 175,133 & G & 6,29 \\
\hline 18 & Apigenin & 37.9 & 269 & 149,117 & G & 29 \\
\hline
\end{tabular}


As a result, the only substance commonly identified in all Ajuga species was forsythoside $A$ and luteolin glucuronide.

The coumaroyl glucose and its glucoside isomer (Figure 4, 5) were determined for $A$. salicifolia extract. The echinacoside (Figure 6) was detected in A. reptans extract. The LC-MS/ MS sprectrum of luteoline derivative (Figure 7), forsytoside A (Figure 8), and luteoline glucuronide (Figure 9) were observed in both $A$. reptans and $A$. genevensis extracts.

The phenolic acids as caffeic acid and flavonoids; apigeninC-hexoside-C-pentoside, quercetin glucuronide, luteolin, and apigenin were identified only for $A$. genevensis. Furthermore, the phenylethanoid glycosides forsythoside $B$ and leonosides A were identified only for $A$. salicifolia. The phytochemical research on Ajuga species focus on the isolation of flavonoids, caffeic and chlorogenic acid type derivates, phenylethanoid glycosides, phytoecdysteroids, iridoids, and diterpenes. ${ }^{12,13,17-24}$ Some anthocyanins, delphinidin, and cyanidin 3-O-sophoroside5-O-glucosides, were acylated with $p$-coumaric acid, while ferulic acid and malonic acid were isolated from the flowers of cell cultures of $A$. reptans. ${ }^{25-27}$

\section{Total phenolic amounts of the extracts}

The amount of total phenolics ranged from 30.0 to $42.2 \mathrm{mg}$ GA equivalent (GAE)/g of the extracts. The phenolic amounts equivalent to $G A$ in all three methanol extracts are shown in Table 4. The highest total phenolic level was found in the methanol extract of $A$. reptans. In previous studies, the total phenolic content of methanol extracts of $A$. reptans and $A$. genevensis has been evaluated to be $20.86 \pm 0.53 \mathrm{mg} \mathrm{RE} / \mathrm{g} \mathrm{dw} \mathrm{w}^{28}$ and $22.63 \pm 0.61 \mathrm{mg} \mathrm{GAE} / \mathrm{g} .{ }^{29}$

\section{$D P P H$ radical scavenging activity}

DPPH radical scavenging activity results are presented in Table 4. The positive control, BHT with $\mathrm{IC}_{50}$ value of $0.06 \mathrm{mg} /$ $\mathrm{mL}$, was found as the most potent antioxidant. The highest radical scavenging activity were obtained for $A$. salicifolia $\left(\mathrm{IC}_{50}: 0.28 \pm 0.01 \mathrm{mg} / \mathrm{mL}\right)$ and $A$. reptans $\left(\mathrm{IC}_{50}: 0.30 \pm 0.01 \mathrm{mg} /\right.$ $\mathrm{mL}$ ) extracts. A correlation was also found between radical scavenging capacity and total phenol content. Previous studies showed the antioxidant activity of the methanol extract of $A$. genevensis flowers as $\mathrm{IC}_{50}: 72.08 \pm 6.02 \mu \mathrm{g} / \mathrm{mL}^{29}$ and $A$. reptans as $I C_{50}: 83.16 \pm 5.21 .^{28}$

However, there have been no reports on the antioxidant activity of $A$. salicifolia. This study is the first to determine the antioxidant activity of $A$. salicifolia.

\section{TEAC assay}

The results obtained for the evaluation of the antioxidant activity using TEAC assay are presented in Table 4 . ABTS ${ }^{\bullet+}$ radical sweeping impact results are in parallel with the results of the $\mathrm{DPPH}$ radical scavenging effect. Extracts from all three plants show $\mathrm{ABTS}^{\bullet+}$ radical scavenging activity at $1 \%$ concentrations, but these effects are not as high as the BHT used as the standard.

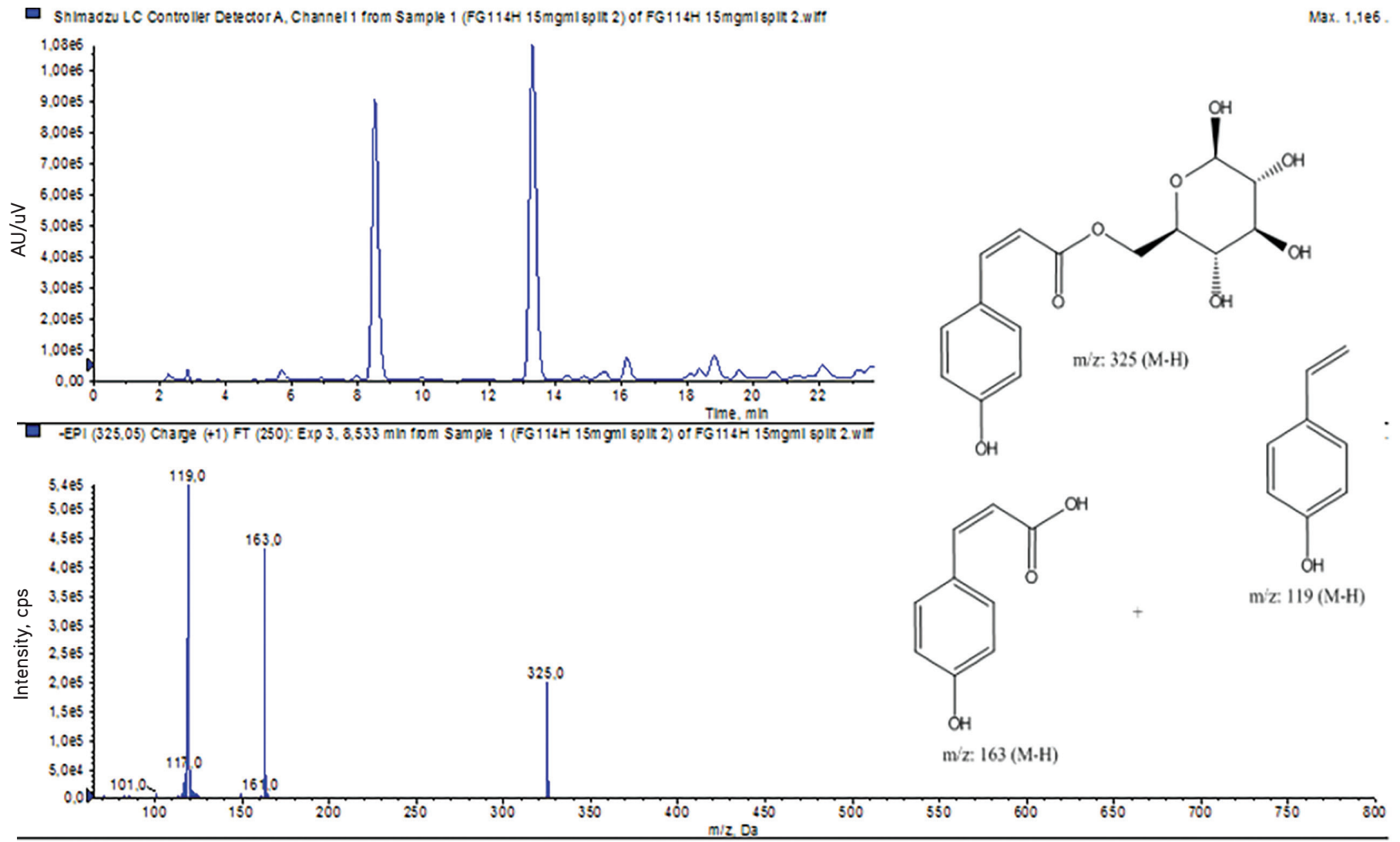

Figure 4. LC-MS/MS sprectrum of in coumaroyl glucose (2) in A. salicifolia extract LC-MS/MS: Liquid chromatography with tandem mass spectrometry 
- Shimadzu LC Controller Detector A, Channel 1 from Sample 1 (FG114H 15mgml split 2) of FG114H 15mgml split 2.wiff

Max. 1,1e6

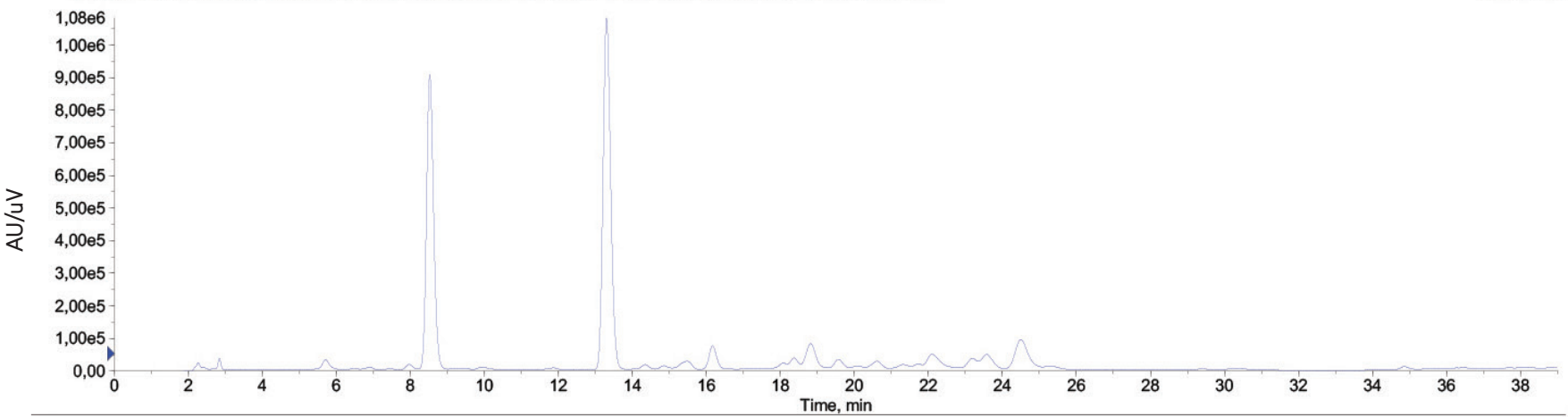

- $-\operatorname{EPI}(325,02)$ Charge (+1) FT (250): Exp 3, 13,273 min from Sample 1 (FG114H 15mgml split 2) of FG114H 15mgml split 2.wiff (Turbo Spray)

Max. $3,5 e 5 \mathrm{cps}$

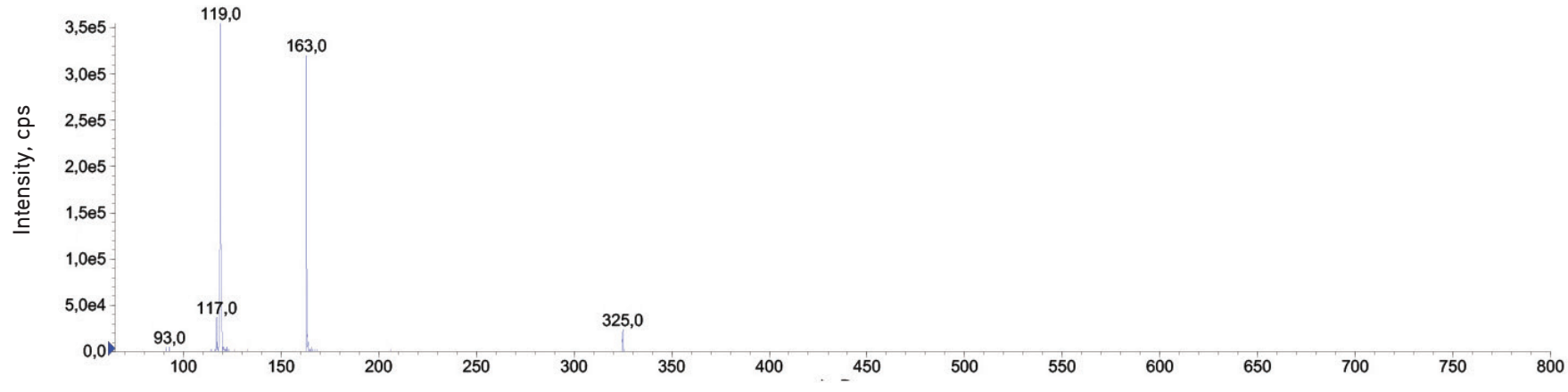

Figure 5. LC-MS/MS sprectrum of in coumaroyl glucoside isomer (4) in A. salicifolia extract LC-MS/MS: Liquid chromatography with tandem mass spectrometry

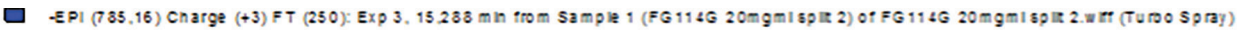
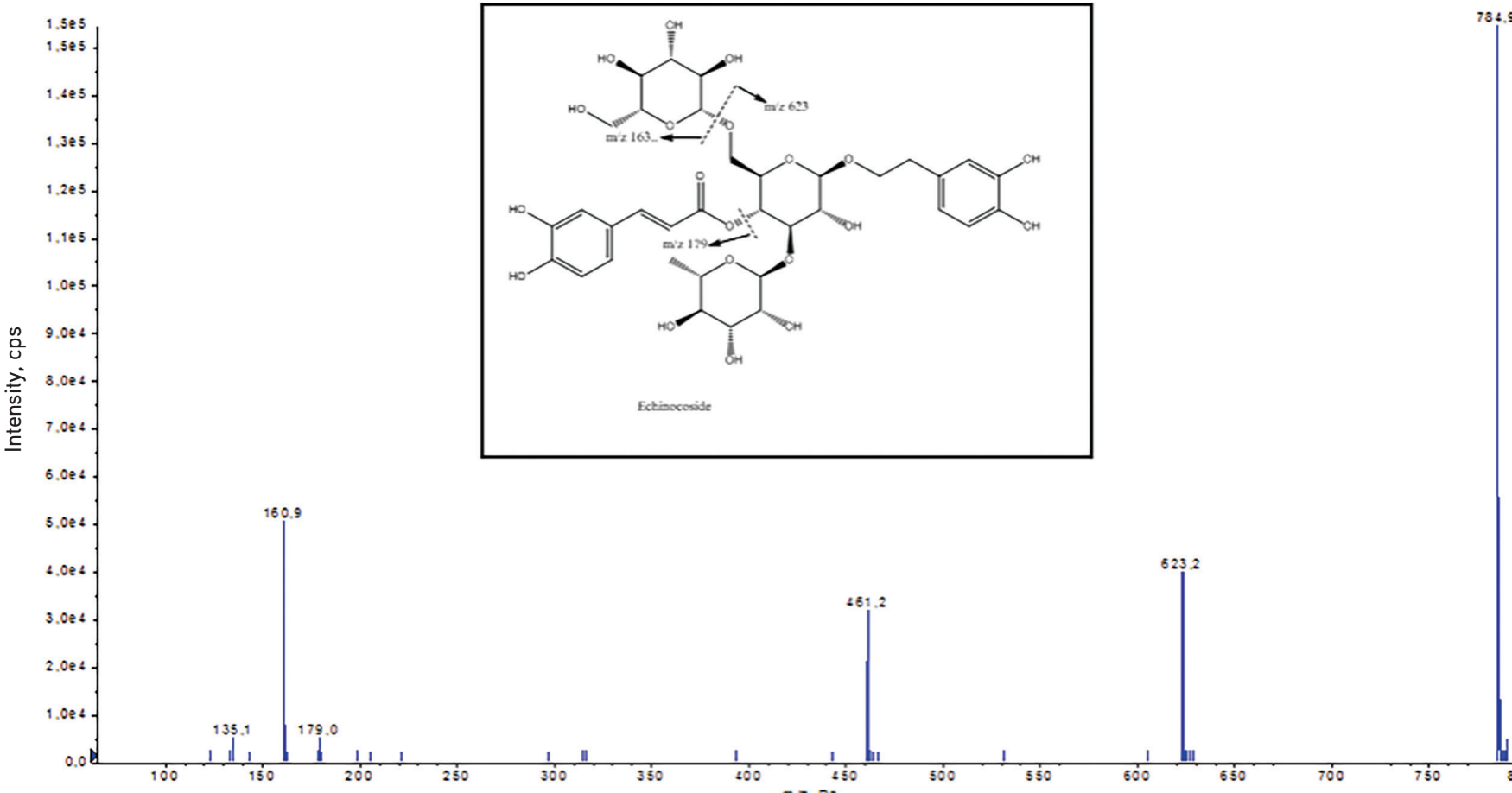

Figure 6. LC-MS/MS sprectrum of echinacoside (7) in A. reptans extract

LC-MS/MS: Liquid chromatography with tandem mass spectrometry 


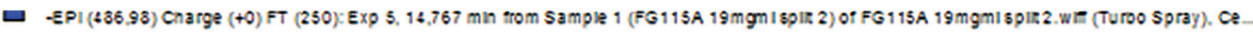

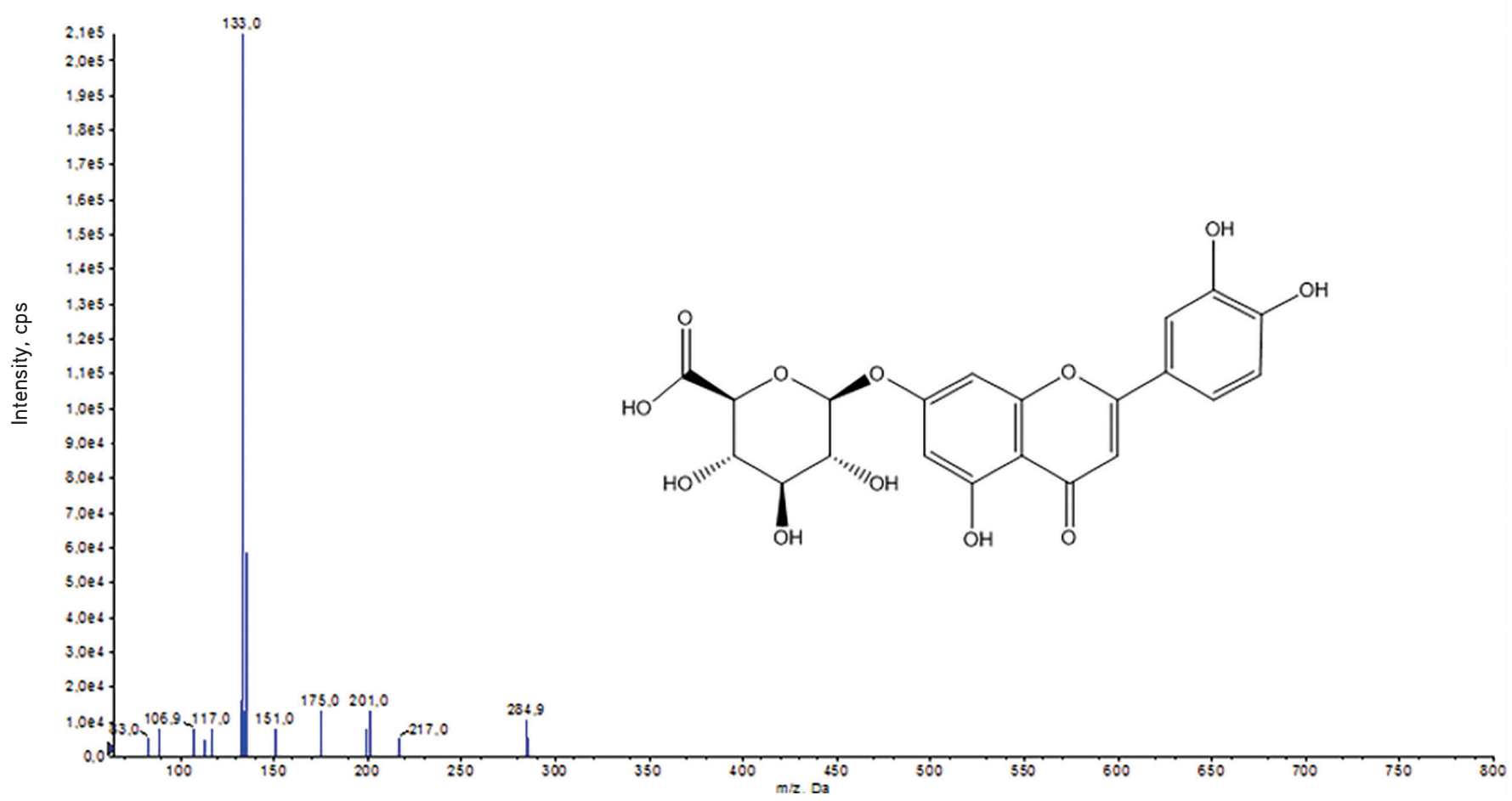

Figure 7. LC-MS/MS sprectrum of luteoline derivative (5) in A. reptans and A. genevensis extracts LC-MS/MS: Liquid chromatography with tandem mass spectrometry

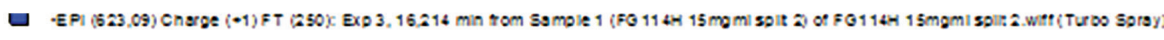

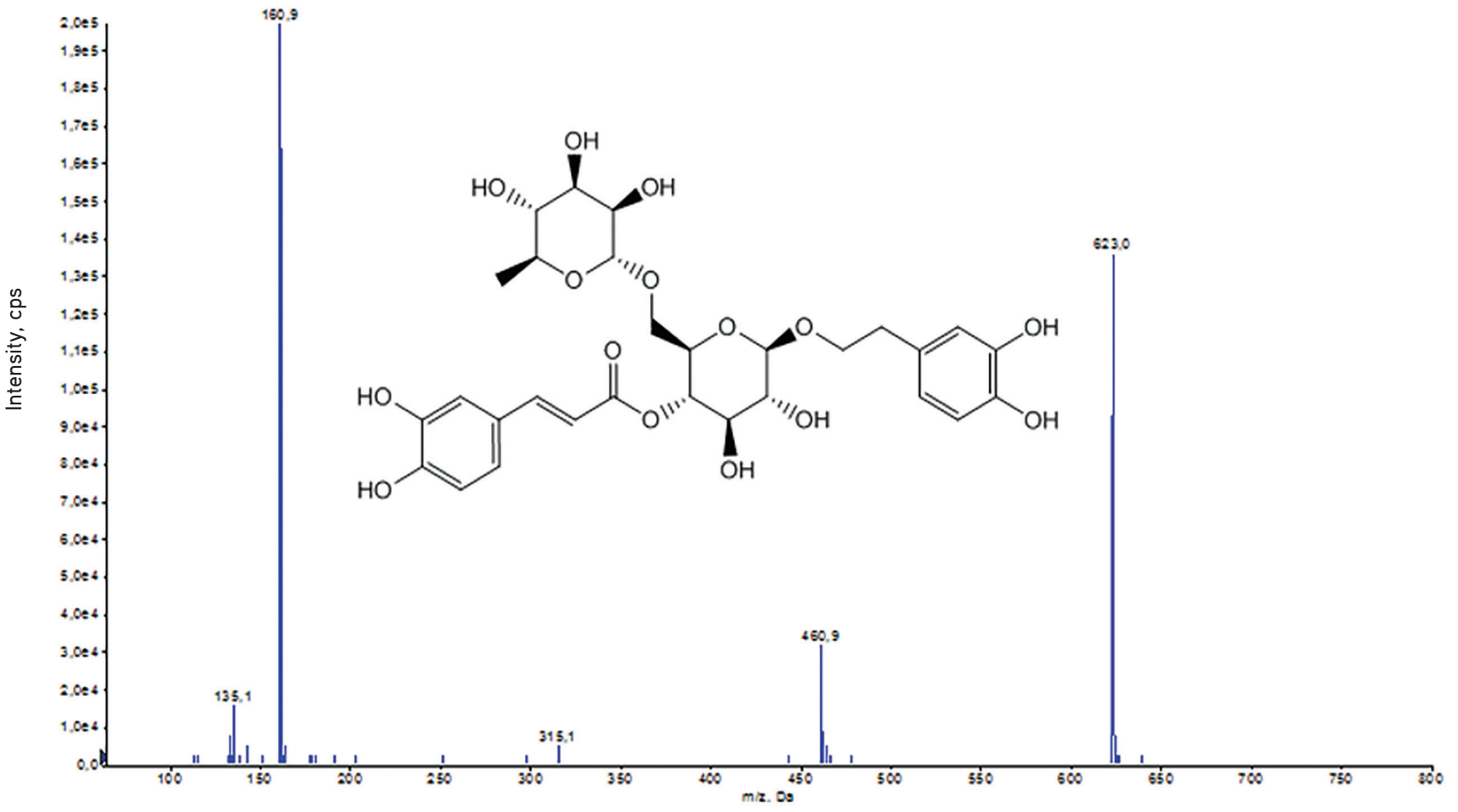

Figure 8. LC-MS/MS sprectrum of forsytoside A (9) in A. reptans and A. genevensis extracts LC-MS/MS: Liquid chromatography with tandem mass spectrometry 


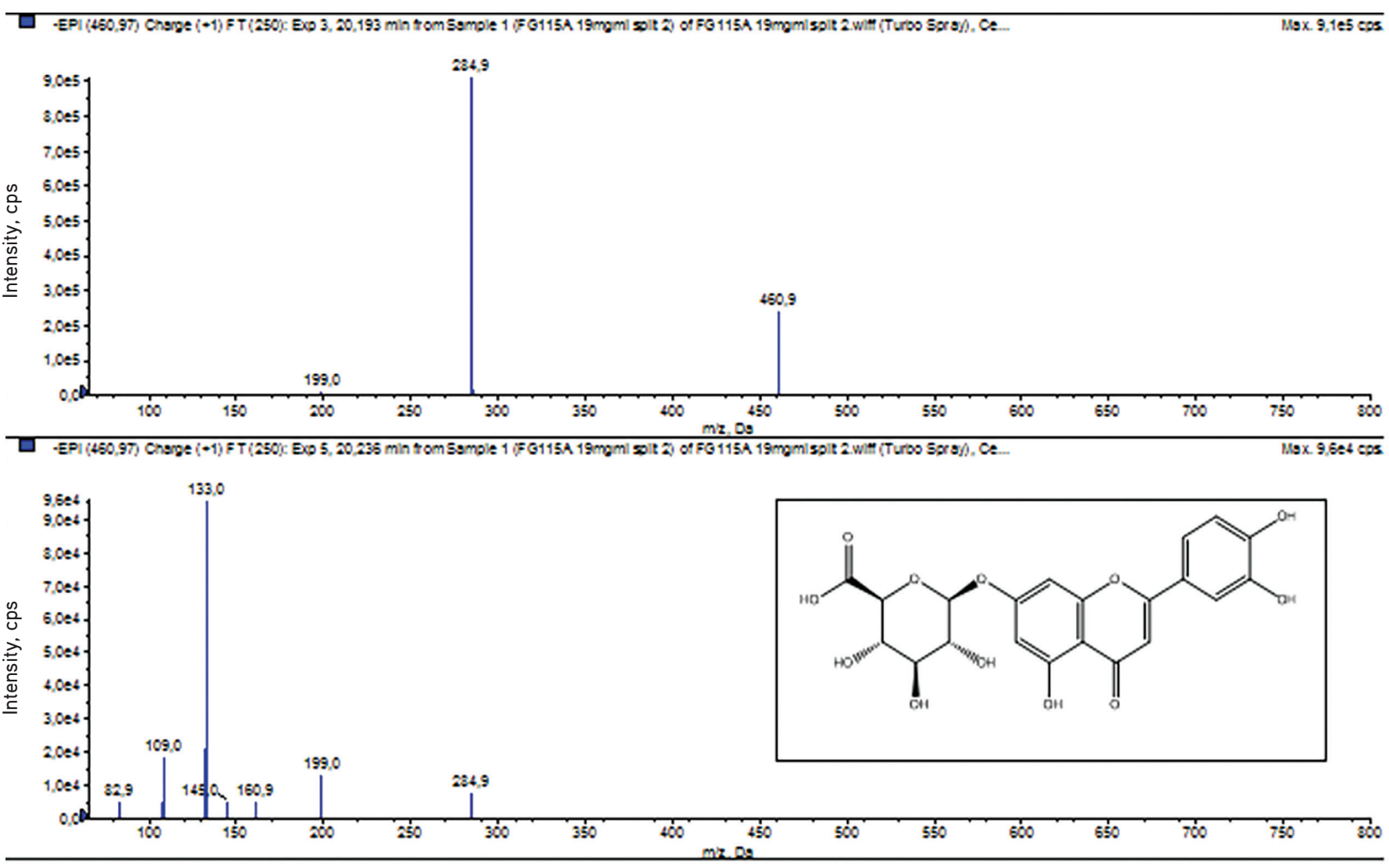

Figure 9. LC-MS/MS sprectrum of luteoline glucuronide (15) in A. reptans and A. genevensis extracts LC-MS/MS: Liquid chromatography with tandem mass spectrometry

\section{Table 4. Total phenolic contents and antioxidant activities of the extracts}

\begin{tabular}{llll} 
Extract & Total phenolic content $(\mathrm{mg} \mathrm{GAE} / \mathrm{g}$ extract)* & DPPH activity $\left(\mathrm{IC} \mathrm{F}_{50}, \mathrm{mg} / \mathrm{mL}\right)$ & TEAC $(\mathrm{mM})$ \\
\hline A. reptans & $42.0 \pm 0.01$ & $0.30 \pm 0.01$ & $1.4 \pm 0.02$ \\
\hline A. salicifolia & $38.0 \pm 0.00$ & $0.28 \pm 0.01$ & $1.5 \pm 0.02$ \\
\hline A. genevensis & $30.0 \pm 0.01$ & $0.44 \pm 0.02$ & $1.2 \pm 0.04$ \\
\hline BHT & - & $0.06 \pm 0.00$ & $1.9 \pm 0.03$ \\
\hline
\end{tabular}

*Total phenolic content was expressed as GAE, each value in the table is represented as the mean \pm SD ( $n=3)$. TEAC: Trolox equivalent antioxidant activity, GAE: Gallic acid equivalent, BHT: Butylated hydroxy toluene, DPPH: 1,1-diphenyl-2-picrylhydrazyl, SD: Standard deviation, IC: Inhibition concentration

There have been no reports on the antioxidant activity performed by a TEAC assay. Antioxidant activity was performed for the first time in this study for A. reptans L., A. salicifolia (L.) Schreber, and $A$. genevensis L. species found in Turkey.

\section{Antimicrobial activity}

The seven different strains tested in this study are presented in Table 5. Ajuga L. extracts showed antimicrobial effect against all microorganisms tested and were more effective against yeasts than bacteria [minimum inhibitory concentration (MIC): $156.25 \mu \mathrm{g} / \mathrm{mL}$ ]. The MIC was $312.5 \mu \mathrm{g} / \mathrm{mL}$ for $E$. coli NRRL B-3008, S. areus ATCC 6538, S. thyphimurium ATCC 13311, and
B. cereus NRRL B-3711 for methanol Ajuga extracts. As a result, the antimicrobial activity was observed in Ajuga extracts, especially against Candida strains.

Data from previous studies on the antimicrobial activity of $A$. reptans, $A$. genevensis, and $A$. salicifolia are listed in Table 2 . To the best of our knowledge, this is the first report on the antimicrobial evaluation for methanol extract of $A$. salicifolia, which was more effective against yeast than bacteria.

\section{CONCLUSION}

We disclose the phytochemical profiles of $A$. reptans, $A$. salicifolia, and $A$. genevensis collected from Turkey. 
Table 5. Minimum inhibitory concentrations $(\mu \mathrm{g} / \mathrm{mL})$

\begin{tabular}{|c|c|c|c|c|c|c|c|}
\hline Microorganisms & Extracts & & & Star & antin & bials & \\
\hline & A. genevensis & A. reptans & A. salicifolia & KT & OXC & AMP & TCY \\
\hline Escherichia coli NRRL B-3008 & 312.5 & 312.5 & 312.5 & - & - & 4 & 16 \\
\hline Staphylococcus aureus ATCC 6538 & 312.5 & 312.5 & 312.5 & - & - & 2 & 8 \\
\hline Salmonella typhimurium ATCC 13311 & 312.5 & 312.5 & 312.5 & - & - & 2 & 8 \\
\hline Bacillus cereus NRRL B-3711 & 312.5 & 312.5 & 312.5 & - & - & 0.5 & 4 \\
\hline Candida albicans ATCC 90028 & 156.25 & 156.25 & 156.25 & 4 & 1 & - & - \\
\hline Candida tropicalis ATCC 1369 & 156.25 & 156.25 & 156.25 & 2 & 0.5 & - & - \\
\hline Candida parapsilosis ATCC 22019 & 156.25 & 156.25 & 156.25 & 2 & 2 & - & - \\
\hline
\end{tabular}

KT: Ketoconazole, OXC: Oxiconazole, AMP: Ampicillin, TCY: Tetracycline, (-): Not tested

The extracts were found to contain valuable metabolites; phenolics acids, coumaroyl glucoside, flavonoids, and phenylethanoid glycosides. The phytochemicals could be employed as potential chemotaxonomic markers because different phytochemicals were observed between the three Ajuga species.

The scope of this study included the biological potential of methanol extracts of $A$. reptans, $A$. salicifolia, and $A$. genevensis evaluated for the first time against some pathogenic strains.

Ajuga species may be considered a valuable natural source against Candida infections and candidal resistance. However, further in vitro and in vivo experiments using different alternative Candida and fungal species are required to validate these screening results.

\section{ACKNOWLEDGMENTS}

This work was supported by the Anadolu University Research Funding (project number: BAP: 080307).

*This work is dedicated to late Hulusi Malyer Prof. MD. for his outstanding contributions to pharmaceutical botany.

Conflict of interest: No conflict of interest was declared by the authors. The authors are solely responsible for the content and writing of this paper.

\section{REFERENCES}

1. The Plant List, 2013 Version 1.1. Last Accessed Date: 07.11.2020. Available from: http://www.theplantlist.org/

2. Köse Ajuga YB. In: Güner A, Aslan S, Ekim T, Vural M, Babaç MT, (eds). Türkiye Bitkileri Listesi (Damarlı Bitkiler). İstanbul: Flora Araștırmaları Derneği ve Nezahat Gökyiğit Botanik Bahçesi Yayını; 2012.

3. Baytop T. Türkiye'de Bitkiler ile Tedavi: Geçmiște ve Bugün. Nobel Tıp Kitabevleri: Ankara; 1999.

4. Njoroge GN, Bussmann RW. Diversity and utilization of antimalarial ethnophytotherapeutic remedies among the Kikuyus (Central Kenya). J Ethnobiol Ethnomed. 2006;2:8.
5. Göger F, Köse YB, Göger G, Demirci F. Phytochemical characterization of phenolics by LC-MS/MS and biological evaluation of Ajuga orientalis from Turkey. Bangladesh J Pharmacol. 2015;10:639-644.

6. Toiu A, Mocan A, Vlase L, Parvu AE, Vodnar DC, Gheldiu AM, Oniga I. Comparative phytochemical profile, antioxidant, antimicrobial and in vivo anti-inflammatory activity of different extracts of traditionally used Romanian Ajuga genevensis L. and A. reptans L. (Lamiaceae). Molecules. 2019;24:1597.

7. Matu EN, Van Staden J. Antibacterial and anti-inflammatory activities of some plants used for medicinal purposes in Kenya. J Ethnopharmacol. 2003;87:35-41.

8. Riaz N, Nawaz SA, Mukhtar N, Malik A, Afza N, Ali S, Choudhary MI. Isolation and enzyme-inhibition studies of the chemical constituents from Ajuga bracteosa. Chem Biodivers. 2007;4:72-83.

9. Debell A, Makonnen E, Zerihun L, Abebe D, Teka F. In-vivo antipyretic studies of the aqueous and ethanol extracts of the leaves of Ajuga remota and Lippia adoensis. Ethiop Med J. 2005;43:111-118.

10. Mamadalieva NZ, El-Readi MZ, Ovidi E, Ashour ML, Hamoud R, Sagdullaev SS, Wink M. Antiproliferative, antimicrobial and antioxidant activities of the chemical constituents of Ajuga turkestanica. Phytopharmacology. 2013;4:1-18.

11. Luan F, Han K, Li M, Zhang T, Liu D, Yu L, Lv H. Ethnomedicinal uses, phytochemistry, pharmacology, and toxicology of species from the genus Ajuga L.: a systematic review. Am J Chin Med. 2019;47:959-1003.

12. Akbay P, Gertsch J, Çalıs I, Heilmann J, Zerbe O, Sticher O. Novel antileukemic sterol glycosides from Ajuga salicifolia. Helv Chim Acta. 2002;85:1930-1942.

13. Akbay P, Çalış I, Heilmann J, Sticher O. Ionone, iridoid and phenylethanoid glycosides from Ajuga salicifolia. Z. Naturforsch C. 2003;58:177-180.

14. Vogl S, Picker P, Mihaly-Bison J, Fakhrudin N, Atanasov AG, Heiss $\mathrm{EH}$, Kopp B. Ethnopharmacological in vitro studies on Austria's folk medicine-an unexplored lore in vitro anti-inflammatory activities of 71 Austrian traditional herbal drugs. J Ethnopharmacol. 2013;149:750-771.

15. Israili ZH, Lyoussi B. Ethnopharmacology of the plants of genus Ajuga. Pak J Pharm Sci. 2009;22:4.

16. Gonzalez-Tejero MR, Casares-Porcel M, Sánchez-Rojas CP, RamiroGutiérrez JM, Molero-Mesa J, Pieroni A, ElJohrig S. Medicinal plants in the Mediterranean area: synthesis of the results of the project Rubia. J Ethnopharmacol. 2008;116:341-357. 
17. Ghita G, Cioanca O, Gille E, Necula R, Zamfirache MM, Stanescu U. Contributions to the phytochemical study of some samples of Ajuga reptans L. and Ajuga genevensis L. Med Sci. 2011;4:7.

18. Malakov PY, Papanov GY, María C, Rodríguez B. Neo-clerodane diterpenoids from Ajuga genevensis. Phytochemistry. 1991;30:40834085.

19. Shoji N, Umeyama A, Sunahara N, Arihara S. Ajureptoside, a novel C9 iridoid glucoside from Ajuga reptans. J Nat Prod. 1992;55:1004-1006.

20. Bozov PI, Papanov GY, Malakov PY, María C, Rodriguez B. A clerodane diterpene from Ajuga salicifolia. Phytochemistry. 1993;34:1173-1175.

21. Carbonell P, Coll J. Ajugatansins, neo-clerodane diterpenes from Ajuga reptans. Phytochem Anal. 2001;12:73-78.

22. Akbay P, Çalıs I, Heilmann J, Sticher O. New stigmastane sterols from Ajuga salicifolia. J Nat Prod. 2003;66:461-465.

23. Ramazanov NS. Phytoecdysteroids and other biologically active compounds from plants of the genus Ajuga. Chem Nat Compd. 2005;41:4.

24. Ono M, Furusawa C, Ozono T, Oda K, Yasuda S, Okawa M, Nohara T. Four new iridoid glucosides from Ajuga reptans. Chem Pharm Bull. 2011;59:1065-1068.

25. Callebaut A, Hendrickx G, Voets AM, Motte JC. Anthocyanins in cell cultures of Ajuga reptans. Phytochemistry. 1990;29:2153-2158.

26. Terahara N, Callebaut A, Ohba R, Nagata T, Ohnishi-Kameyama M, Suzuki M. Triacylated anthocyanins from Ajuga reptans flowers and cell cultures. Phytochemistry. 1996;42:199-203.

27. Terahara N, Callebaut A, Ohba R, Nagata T, Ohnishi-Kameyama M, Suzuki M. Acylated anthocyanidin 3-sophoroside-5glucosides from Ajuga reptans flowers and the corresponding cell cultures. Phytochemistry. 2001;58:493-500.

28. Toiu A, Vlase L, Gheldiu AM, Vodnar D, Oniga I. Evaluation of the antioxidant and antibacterial potential of bioactive compounds from Ajuga reptans extracts. Farmacia. 2017;65:351-355.

29. Toiu A, Vlase L, Arsene AL, Vodnar DC, Oniga I. LC/UV/MS profile of polyphenols, antioxidant and antimicrobial effects of Ajuga genevensis $L$. extracts. Farmacia. 2016;64:53-57.

30. Singleton VL, Orthofer R, Lamuela-Raventos RM. Analysis of total phenols and other oxidation substrates and antioxidants by means of folin-ciocalteu reagent. Methods Enzymol. 1999;299:152-178.

31. Kumarasamy Y, Byres M, Cox PJ, Jaspars M, Nahar L, Sarker SD. Screening seeds of some Scottish plants for free radical scavenging activity. Phytother Res. 2007;2:615-621.

32. Papandreou MA, Kanakis CD, Polissiou MG, Efthimiopoulos S, Cordopatis $P$, Margarity M, Lamari FN. Inhibitory activity on amyloid- $\beta$ aggregation and antioxidant properties of Crocus sativus stigmas extract and its crocin constituents. J Agric Food Chem. 2006;54:8762-8768.

33. Clinical and Laboratory Standards Institute (CLSI). Reference method for broth dilution antifungal susceptibility testing of yeast. Approved standard CLSI 27-A3. (3rd ed). Pennsylvania, USA: Clinical and Laboratory Standards Institute; 2008.
34. Clinical and Laboratory Standarts Institute (CLSI). Methods for dilution antimicrobial susceptibility tests for bacteria that grow aerobically CLSI M7-A7. Pennsylvania, USA: Clinical and Laboratory Standards Institute; 2006.

35. Göger G, Demirci B, Ilgın S, Demirci F. Antimicrobial and toxicity profiles evaluation of the chamomile (Matricaria recutita L.) essential oil combination with standard antimicrobial agents. Ind Crops Prod. 2018;120:279-285.

36. Calcagno MP, Camps F, Coll J, Mele, E, Sanchez-Baeza, F. New phytoecdysteroids from roots of Ajuga reptans varieties. Tetrahedron. 1996;52:10137-10146.

37. Zabka M, Pavela R, Gabrielova-Slezakova L. Promising antifungal effect of some Euro-Asiatic plants against dangerous pathogenic and toxinogenic fungi. J Sci Food Agric. 2011;91:492-497.

38. Butenko LE, Kuleshova SA, Postnikova NV, Lovyagina SA. The Ajuga genevensis L. chemical composition and the biological activity study. Eur J Nat Hist. 2011;5:31-33.

39. Abdullah E, Raus RA, Jamal P. Extraction and evaluation of antibacterial activity from selected flowering plants. Am J Med. 2012;3:27-32.

40. Yildirim AB, Karakas FP, Turker AU. In vitro antibacterial and antitumor activities of some medicinal plant extracts, growing in Turkey. Asian Pac J Trop Med. 2013;6:616-624.

41. Gavrilova V, Kajdzanoska M, Gjamovski V, Stefova M. Separation, Characterization and quantification of phenolic compounds in blueberries

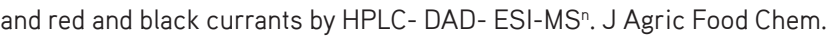
2011;59:4009-4018.

42. Shimomura H, Sashida Y, Ogawa K. Iridoid glucosides and phenylpropanoid glycosides in Ajuga species of Japan. Phytochemistry. 1987;26:19811983.

43. Cretkovikj I, Stefkov G, Acevska J, Stanoeva JP, Karapandzova M, Stefova M, Kulevanova S. Polyphenolic characterization and chromatographic methods for fast assessment of culinary Salvia species from South East Europe. J Chromatogr A. 2013;1282:38-45.

44. Ferreres F, Silva BM, Andrade PB, Seabra RM, Ferreira MA. Approach to the study of C-glycosyl flavones by ion trap HPLC-PAD-ESI/MS/ MS: application to seeds of quince (Cydonia oblonga). Phytochem Anal. 2003;14:352-359.

45. Mitreski I, Stanoeva JP, Stefova M, Stefkov G, Kulevanova S. Polyphenols in representative teucrium species in the flora of R. Macedonia: LC/DAD/ ESI-MS n profile and content. Nat Prod Commun. 2014;9:175-180.

46. Petreska J, Stefova M, Ferreres F, Moreno DA, Tomás-Barberán FA, Stefkov G, Gil-Izquierdo A. Potential bioactive phenolics of Macedonian Sideritis species used for medicinal "Mountain Tea". Food Chem. 2011;125:13-20.

47. Tao Y, Chen Z, Zhang Y, Wang Y, Cheng Y. Immobilized magnetic beads based multi-target affinity selection coupled with high performance liquid chromatography-mass spectrometry for screening anti-diabetic compounds from a Chinese medicine "Tang-Zhi-Qing". J Pharm Biomed. 2013;7:190-201. 